\title{
Viral Infections Among Patients with Acute Lower Respiratory Tract Infections in the Pediatric Intensive Care Unit
}

\author{
Çocuk Yoğun Bakım Ünitesinde Alt Solunum Yolu Enfeksiyonu Tanısıyla Yatan \\ Hastalarda Viral Patojen Sıklığı ve Hastaların Klinik Özellikleri
}

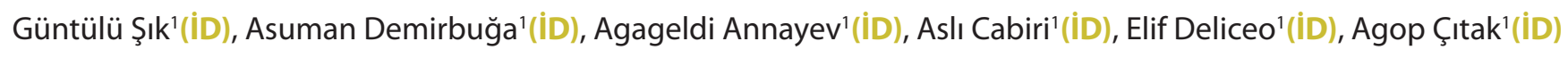 \\ ' Division of Pediatric Intensive Care, Acibadem Mehmet Ali Aydinlar University School of Medicine, Istanbul, Turkey
}

Cite this article as: Şık G, Demirbuğa A, Annayev A, Cabiri A, Deliceo E, Çıtak A. Viral infections among patients with acute lower respiratory tract infections in the pediatric intensive care unit. J Pediatr Inf 2020;14(1):e27-e32.

\begin{abstract}
Objective: We aimed to determine the frequency of viral pathogen and clinical characteristics of patients hospitalized in the pediatric intensive care unit with the diagnosis of acute lower respiratory tract infection.
\end{abstract}

Material and Methods: Eighty patients with laboratory-confirmed viral infections among children admitted to the pediatric intensive care unit (PICU) between November 2016 and September 2017 with a suspicion of viral infection were included. Diagnosis was made using a respiratory viral panel including adenovirus (AV), metapneumovirus (MV), parainfluenza virus (PIV) 1, PIV 2, PIV 3, PIV 4, influenza virus (IV) A and IVB, rhinovirus (RV), respiratory syncytial virus (RSV) A and RSV B, and multiplex polymerase chain reaction (PCR). Tracheal aspiration specimens were obtained from intubated patients and nasopharyngeal swab specimens were obtained from the remaining patients.

Results: A total of 514 children were admitted to our PICU. Of 123 patients with lower respiratory tract infection, specimens from a nasopharyngeal swab or tracheal aspiration were obtained and tested using a viral infection panel and multiplex PCR. Mean age of the patients was $6.1 \pm 3.6$ months, $60 \%(n=48)$ of the children were boys. Ninety-three positive results were obtained from 80 patients. The most common viral pathogens were RSV $(A+B)(n=36,45 \%), \operatorname{RV}(n=26,32.5 \%)$, PIV 1 $(n=7,8.7 \%), A V(n=6,7.5 \%)$, human MV $(n=5,6.2 \%)$, IVA ( $n=4,5 \%)$, and IVB $(n=4,5 \%)$. The most common dual infection was RV and RSV B. Viral pathogen detection was the highest in december $(n=15)$ and february $(n=13)$. High-flow oxygen therapy was needed in $57.5 \%$ of patients, and $12.5 \%$ had non-invasive mechanical ventilation. Twenty-seven (33.7\%)
Öz

Giriş: Çalışmada, çocuk yoğun bakım ünitesi (YBÜ)'nde alt solunum yolu enfeksiyonu tanısıyla yatan hastalarda viral patojen sıklığının ve hastaların klinik özelliklerinin belirlenmesi amaçlanmıştır.

Gereç ve Yöntemler: Kasım 2016-Eylül 2017 tarihleri arasında çocuk YBÜ'ye yatan, viral enfeksiyon şüphesiyle viral solunum paneli gönderilen ve pozitif saptanan 80 hasta çalışmaya dahil edildi. Solunum panelinde adenovirüs (ADV), metapnömovirüs (MPV), parainfluenza virüs (PIV) 1, PIV 2, PIV 3, PIV 4, influenza virüs (IV) A ve IVB, rinovirüs (RV), respiratuvar sinsityal virüs (RSV) A ve RSV B multipleks polimeraz zincir reaksiyonu (PCR) ile çalışıldı. Örnekler entübe olmayan hastalarda nazofarengeal sürüntüden, entübe olan hastalarda trakeal aspirasyon materyalinden alındı.

Bulgular: Kasım 2016-Eylül 2017 tarihleri arasında YBÜ'ye toplam 514 hasta yatırıldı. Alt solunum yolu enfeksiyonu tanısıyla yatan 123 hastada nazofarengeal sürüntü veya trakeal aspirasyon materyalinden örnek alınarak Multipleks PCR ile viral enfeksiyon paneli çalışıldı. Ortalama yaş 6.1 \pm 3.6 aydı, hastaların \%60 ( $n=48)^{\prime} ı$ erkekti. Seksen hastada 93 pozitiflik saptandı. On üç (\%16) hastada çift etken pozitifliği vardı. En sık saptanan viral ajanlar 36 (\%45) hastada RSV (A + B), 26 (\%27.9) hastada RV, 7 (\%7.5) hastada PIV 1, 6 (\%6.4) hastada ADV, 5 (\%5.3) hastada human MPV, 4 (\%4.3) hastada IVA, 4 (\%4.3) hastada IVB idi. Çift etken pozitifliğinde en sık RV ve RSV B pozitifliği saptandı. En çok viral etken pozitifliği saptanan aylar aralık $(n=15)$ ve şubattı $(n=13)$. Hastaların \%57'sine yüksek akımlı oksijen tedavisi, \%12'sine noninvaziv mekanik ventilasyon uygulandı. 
patients had to be intubated due to insufficient ventilation with noninvasive methods. The most commonly detected viral pathogen among the intubated patients was RSV B. The average intensive care length of stay for all children was $10.1 \pm 3.6$ days.

Conclusion: Viral infections are common among critically ill children in PICUs. Hospital length of stay, morbidity, and mortality increase with underlying chronic diseases or dual infections. Early diagnosis of viral infections decreases unnecessary antibiotic use.

Keywords: Pediatric intensive care, viral infection, lower respiratory tract infections, multiplex PCR, respiratory viral panel

\section{Introduction}

Viral infections are an important cause of morbidity and mortality in childhood all over the world. The most common causes of lower respiratory tract infections (LRTIs), in particular, are viral infections. Viruses are responsible for $30-70 \%$ of acute RTIs where respiratory syncytial virus (RSV), influenza virus (IV), parainfluenza virus (PIV), bocavirus, metapneumovirus (MPV), adenovirus (AV), rhinovirus (RV), enterovirus, and coronaviruses account for the majority of these cases (1-3). Approximately, 12 million children are hospitalized each year with lower respiratory tract infections. More than 2 million children died in 2010 due to serious LRTI (4-6).

The inability to describe etiologic factors in patients with LRTIs admitted to the pediatric intensive care unit (PICU) results in unnecessary and inappropriate use of antibiotics, thus lengthening hospital stays and causing antibiotic resistance. As laboratory techniques develop for viral detection methods, isolation of these pathogens from respiratory secretions is becoming easier and more common.

The aim of this study was to describe the viral detection profile and clinical characteristics of children admitted to the PICU with severe acute RTIs and evaluate the effects of detection of etiology on treatment and prognosis.

\section{Materials and Methods}

Eighty patients with laboratory-confirmed viral infections among children with acute LRTIs, who were admitted to Acıbadem Mehmet Ali Aydınlar University, Faculty of Medicine, PICU, between November 2016 and September 2017, were included. Patient records were reviewed retrospectively. The study protocol was approved by the Ethics Committee of Acibadem Mehmet Ali Aydinlar University Medical Faculty (2017-10/11)

Acute LRTIs were diagnosed according to the clinical guidelines recommended by the World Health Organization $(5,6)$. The inclusion criteria were as follows:

- cough or difficulty in breathing and breathing faster than 60 breaths/min (infants $<2$ months),

- cough or difficulty in breathing and breathing faster than 50 breaths/min (2-12 months),
Yirmi yedi hasta noninvaziv yöntemlerin yetersiz kalması nedeniyle entübe olarak izlendi. Entübe olarak izlenen hastalarda en sık RSV B pozitifti. Tüm hastalar için ortalama YBÜ yatış süresi $10.1 \pm 3.6$ gündü.

Sonuç: Çocuk YBÜ'de yatan kritik hasta çocuklarda viral enfeksiyonlar sık görülmektedir. Altta yatan kronik hastalığı olanlarda veya çift viral etken pozitifliği saptananlarda hastane yatış süresi, morbidite ve mortalite artmaktadır. Hastalara erken tanı konulması gereksiz antibiyotik kullanımını azaltır.

Anahtar Kelimeler: Alt solunum yolu enfeksiyonu, viral enfeksiyon, çocuk yoğun bakım ünitesi, viral solunum paneli

- cough or difficulty in breathing and breathing faster than 40 breaths/min (1-5 years)

- $\quad$ sudden-onset fever $>38^{\circ} \mathrm{C}$, cough or sore throat, shortness of breath or difficulty in breathing (children $>5$ years of age) or

- $\quad$ severe pneumonia (any child aged 2 months to 5 years with cough or difficulty in breathing, and any of the following general danger signs: inability to drink or breastfeed, vomiting everything, convulsions, lethargic or unconscious, chest indrawing, or stridor in a calm child),

\section{- pneumonia requiring hospitalization}

Diagnosis was made using a respiratory viral panel including adenovirus (AV), metapneumovirus (MV), parainfluenza virus 1 (PIV 1), parainfluenza virus 2 (PIV 2), parainfluenza virus 3 (PIV 3), parainfluenza virus 4 (PIV 4), influenza A (IA) and B (IB) viruses, rhinovirus (RV), respiratory syncytial virus $A$ (RSV $A$ ) and $B(R S V B)$, and multiplex polymerase chain reaction (PCR). Tracheal aspiration specimens were obtained from intubated patients and nasopharyngeal swab specimens were obtained from the remaining patients. Nasopharyngeal aspirate (NPA) or tracheal aspiration was collected from the patients on the first day of admission. Demographic information and medical test results were obtained using standardized forms.

On admission to hospital, laboratory data (total leukocyte and lymphocyte count, C-reactive protein, procalcitonin) and blood culture waererecorded. Patients with leukocytosis, high procalcitonin levels $(0.5 \mathrm{ng} / \mathrm{mL})$ and infiltration on chest X-ray with fever (axillary $>37.5^{\circ} \mathrm{C}$ ) were treated with antibiotics (ampicillin-sulbactam 200 mg/kg/days) until blood culture results. Antibiotic therapy was discontinued in patients whose blood culture was sterile and PCR positive. Obtained data were analyzed using NCSS (Number Cruncher Statistical System) 2007 and PASS 2008 Statistical Software (Utah, USA).

\section{Results}

A total of 514 children were admitted to our PICU between November 2016 and September 2017. Of 123 patients with lower respiratory tract infection, specimens from nasopharyngeal swabs or tracheal aspirations were obtained and tested 
using a viral infection panel and multiplex PCR. Ninety-three positive results were obtained from 80 patients. Mean age of the patients was $6.1 \pm 3.6$ months, and $60 \%(n=48)$ of the children were males. Twenty-one patients $(26.2 \%)$ of the positive-resulted specimens were obtained from tracheal aspirations; while fifty-nine patients (73.8\%) from nasopharyngeal swabs. Thirteen patients had a dual infection. Most common viral pathogens were RSV in 36 (45\%) patients, RSV B in 19 pa- tients (23.8\%), RSV A in 17 patients (21.3\%), rhinovirus in 26 patients (32.5\%), parainfluenza virus 1 in 7 patients (8.7\%), adenovirus in 6 patients (7.5\%), human metapneumovirus in 5 patients (6.2\%), influenza $A$ in 4 patients $(5 \%)$, and influenza $B$ in 4 patients (5\%) (Figure 1). The most common dual infection was rhinovirus $(n=9)$. Viral pathogen detection was the highest in December $(n=17)$ and February $(n=16)$. Figure 2 summarizes the monthly distribution of viral pathogens.

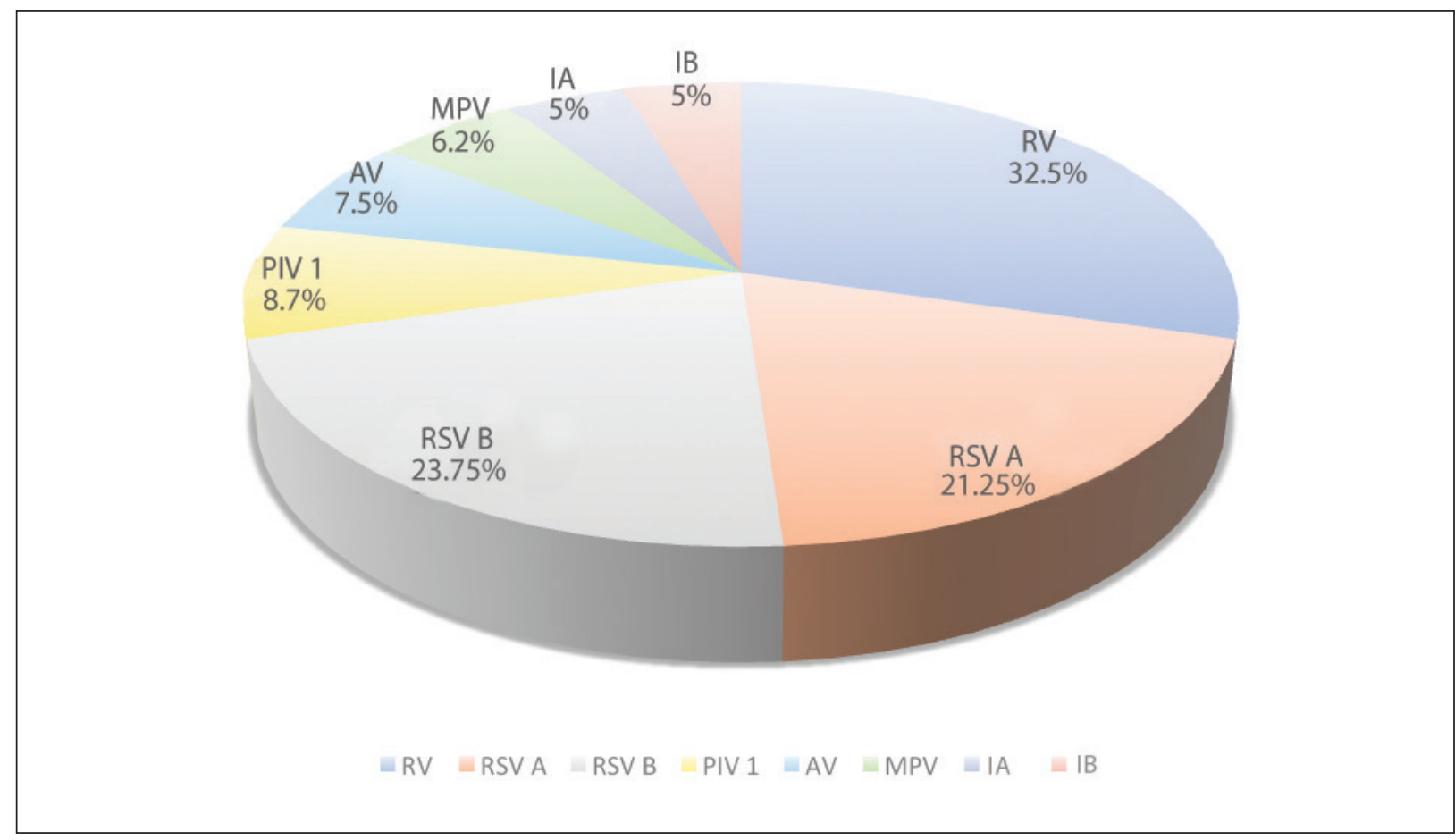

Figure 1. Frequency of viruses.

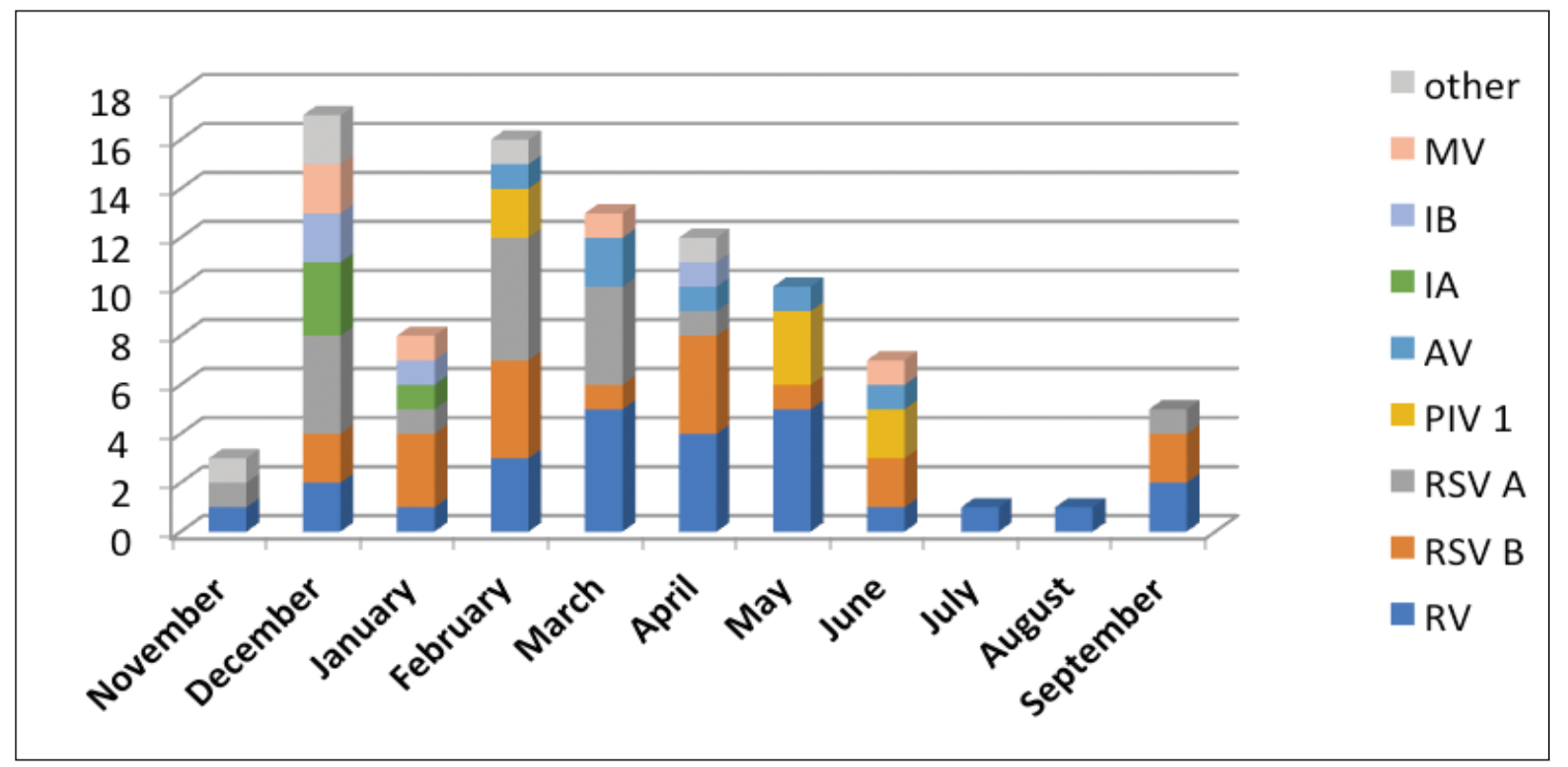

Figure 2. The monthly distribution of viruses. 
Table 1. Demographic and clinical data

\begin{tabular}{|l|l|}
\hline & Mean \pm SD, n (\%) \\
\hline Sex (male/female) & $48 / 32(60 / 40)$ \\
\hline Age (months) & $6.1 \pm 3.6$ \\
\hline Tracheal aspiration/nasopharyngeal swab specimens & $21 / 59(26 / 74)$ \\
\hline HFO therapy & $46(57.5 \%)$ \\
\hline NIV & $10(12.5 \%)$ \\
\hline Intubated & $27(33.7 \%)$ \\
\hline PICU stay (day) & $10.1 \pm 3.6$ \\
\hline $\begin{array}{l}\text { HFO: High flow oxygen, NIV: Non-invasive ventilation, PICU: Pediatric intensive care } \\
\text { unit. }\end{array}$ \\
\hline
\end{tabular}

Table 2. Primary symptoms on admission

\begin{tabular}{|l|l|}
\hline Symptoms on admission & $\mathbf{n}(\mathbf{\% )}$ \\
\hline Cough & $32(40)$ \\
\hline Wheezing & $30(37.5)$ \\
\hline Rhinorrhea & $21(26.3)$ \\
\hline Fever & $14(17.5)$ \\
\hline Convulsions & $7(8.7)$ \\
\hline Cyanosis & $6(7.5)$ \\
\hline & \\
\hline
\end{tabular}

Primary symptoms of the patients on admission to hospital were cough (40\%), wheezing (37.5\%), rhinorrhea (26.3\%), fever (17.5\%), and cyanosis (7.5\%) (Table 2). All patients had respiratory distress at admission. The most frequent diagnoses on admission were acute bronchiolitis (48.7\%), pneumo- nia (37.5\%), febrile status epilepticus (8.7\%) and pertussis (5\%). Four patients with pertussis had co-infections; 2 patients were positive for RSV, the other two had RV.

Eighty-six patients were treated with antibiotics (ampicillin-sulbactam $200 \mathrm{mg} / \mathrm{kg} /$ day) until blood culture results. Fifty-six of these patients were PCR positive, and 30 of them PCR negative. Sterile resulting blood cultures were reported at 72 h. Antibiotic therapy was discontinued in twenty-six patients whose blood culture was sterile and PCR positive. However, antibiotic treatment was continued in 30 patients who needed respiratory support.

High-flow oxygen therapy was needed in $57.5 \%$ of patients $(n=46), 12.5 \%(n=10)$ had noninvasive mechanical ventilation. Twenty-seven patients (33.7\%) had to be intubated due to insufficient ventilation using noninvasive methods. Thirty-four viral pathogens were detected in 27 intubated patients. These pathogens were RSV (44.4\%), RV (23.5\%), PIV (8.8\%), AV (8.8\%), IA (5.8\%), and IB (5.8\%) (Figure 3).

The average PICU length of stay for all children was $10.1 \pm$ 3.6 days. A patient who was positive for PIV 1 had the longest PICU stay of 15 days. Three patients died, two had dual viral infections (RSV and rhinovirus), one of whom had severe combined immunodeficiency, the other had hypoplastic left heart syndrome. The cause of mortality in the third patient was fatal pertussis accompanied by RSV infection.

\section{Discussion}

LRTIs are among the most common causes of morbidity and mortality worldwide and are responsible for $18 \%$ of

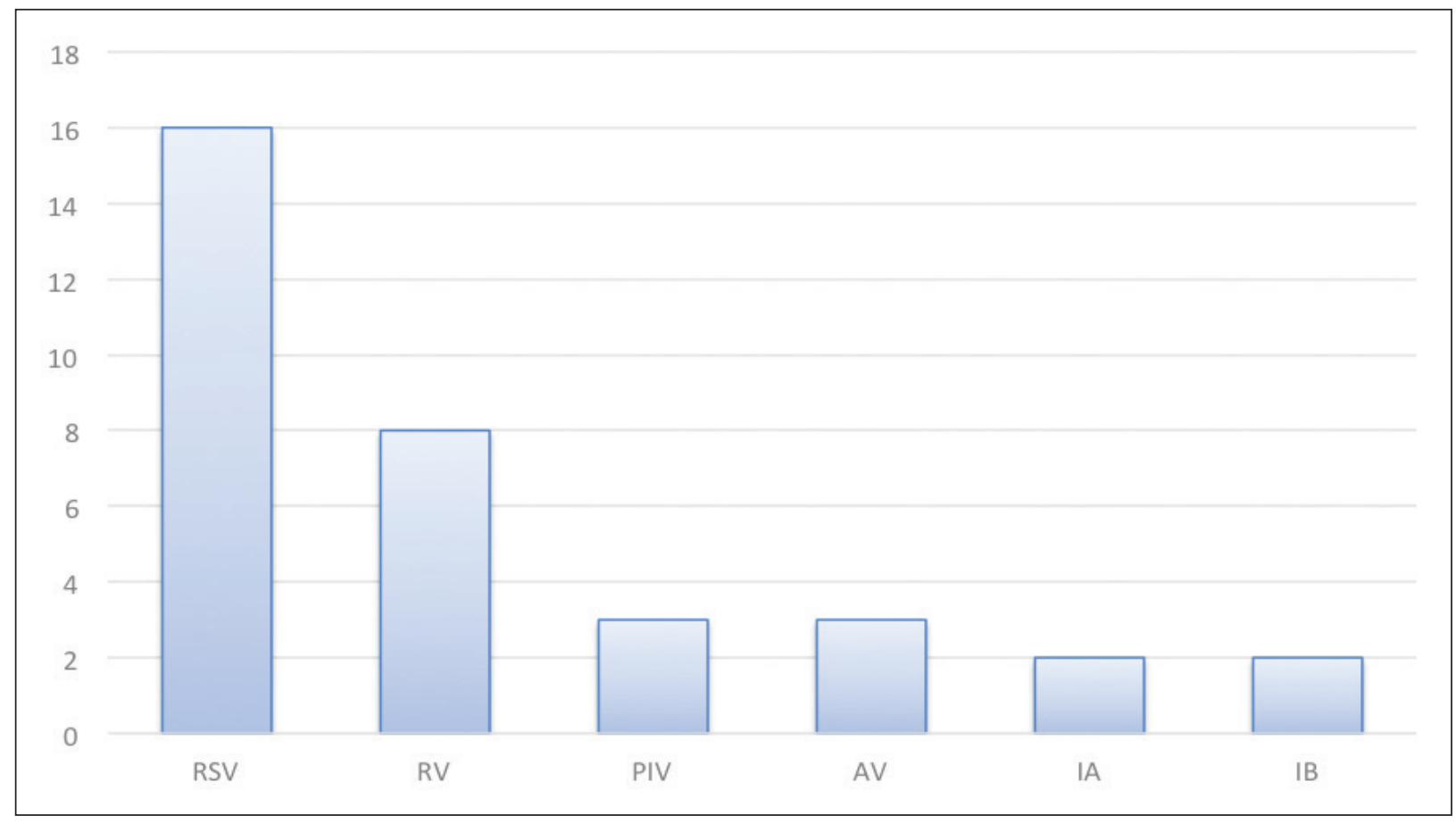

Figure 3. Viruses detected in intubated patients. 
deaths in children aged under 5 years $(7,8)$. The etiology in LRTIs differs according to age; however, viral agents are the most frequently encountered pathogens, especially in children aged under 5 years. Among the most common pathogens are rhinovirus, respiratory syncytial virus, influenza $A$ and $B$, parainfluenza virus, metapneumovirus, and adenovirus $(9,10)$.

Uyar et al. have detected viral antigens in 35 (28.2\%) of specimens obtained from 124 children aged 0-5 years with clinically diagnosed LRTIs (11). The viral antigens detected from specimens were as follows; RSV $40 \%$, PIV types $28.6 \%$, influenza B virus $11.4 \%$, coronavirus $8.6 \%$, influenza A virus $5.7 \%$, and adenovirus $5.7 \%$. Yüksel et al. have demonstrated viral pathogen positivity in $25.2 \%$ of children with LRTI symptoms (12). The most common viruses were RSV and AV (31.5\%), followed by parainfluenza $(26.3 \%)$ and influenza (23.6\%), respectively. A study by Pelit et al. have presented $46.9 \%$ viral antigen positivity in pediatric patients (13). The most common virus was RSV (35.3\%), $4.2 \%$ of patients had influenza $A$ virus, and $1.9 \%$ had influenza B virus.

Our study showed RSV as the most common viral cause in LRTIs, accounting for $45 \%$ of all patients. Nineteen patients had RSV B (23.8\%) positivity, 17 patients had RSV A (21.3\%) infection. The other common pathogens were as follows; rhinovirus (32.5\%), parainfluenza virus $1(8.7 \%)$, adenovirus (7.5\%), human metapneumovirus (6.2\%), influenza $A(5 \%)$, and influenza B (5\%) virus.

It is presumed that more than $95 \%$ of all children are infected with RSV in their first 2 years (13). RSV was the most commonly isolated pathogen in our study. While causing common cold in adults, RSV is responsible for LRTIs in $40 \%$ of infants and children. It has been shown that the most common pathogen in children younger than 5 years with pneumonia is RSV (15). Eriksson et al. have detected RSV in 89 of 135 children with LRTIs (66\%), and Kuypers et al. have shown RSV in 239 of 1038 children $(23 \%)(16,17)$. Studies from our country show differences in the frequency of RSV, but a study from Karakoyun et al. have reported $63 \%$ positivity, whereas Kanra et al. have detected $29.5 \%$ positivity in their study $(18,19)$.

Rhinovirus was the most commonly detected virus following RSV in our study. Human rhinoviruses (HRV) are usually associated with mild respiratory symptoms in children. However, some studies have found that HRV can cause severe disease, especially when the patient is co-infected with a second virus, immunodeficiency diseases, congenital heart diseases or prematurity (20). Twenty-six patients were rhinovirus positive. In addition, nine patients had dual infections, five patients had a history of prematurity, four patients had congenital heart diseases, and one patient had immunodeficiency. We believe these to be facilitating factors for rhinovirus infections in the lower respiratory tract.

Molecular methods such as multiplex PCR for the diagnosis of respiratory viral infections allow testing for multiple agents at the same time, detecting more than one viral pathogen in a patient. Akcalı et al. have diagnosed viral agents in $41.8 \%$ of patients with LRTIs (21). Further, they have detected multiple pathogens in $10.4 \%$. Four specimens were RSV-rhinovirus, one specimen was RSV-coronavirus, one specimen was rhinovirus-coronavirus, and one specimen was RSV- rhinovirus-coronavirus. A study including children in the PICU by Frobert et al. have reported the multiple infection rate as $35 \%$ and RSV was the most commonly detected virus in multiple viral infections with a rate of $24.3 \%$ (22). In our study, 13 patients had multiple viral infections. The most frequent diagnosis in multiple infections was RV and RSV.

Viral etiologies causing LRTIs in children and frequency can differ according to the seasons and months of the year (23). January and March are the peak seasons for viral infections in England and the United States of America; as for areas with more temperate climates, hospital admissions increase during December and April. Studies in Turkey show an increase in viral LRTIs during December (24). Similar to previous studies, viral pathogen detection was most common during December and February in our study.

RSV infections can cause a more severe clinical presentation and higher mortality rates. Although mortality rates in previously healthy babies were reported as $0.5-1 \%$, it is between $3-5 \%$ for premature and chronic lung disease, and the mortality rate dramatically increases to $33 \%$ in children with severe heart diseases $(25,26)$. RSV infection was positive in 3 patients who died during our study. One patient, who was co-infected with Bordetella pertussis, died of multiple organ failure and severe pulmonary hypertension. The other two patients were diagnosed as having congenital heart disease and combined immune deficiency, respectively. Both had dual viral infection of RSV and rhinovirus. Furthermore, RSV was the most commonly isolated pathogen from patients requiring invasive mechanical ventilation due to severe respiratory failure. We argue that RSV causes more severe infections compared with other viral pathogens and can be mortal in pertussis co-infection or with an underlying chronic disease.

Antibiotic use is common in patients in PICUs with LRTIs due to high fever, the presence of pathologic radiologic findings, and severe clinical presentation of children aged under one year. With laboratory confirmation of viral pathogens, early termination of antibiotic treatment can prevent antibiotic resistance, decrease treatment costs, and shorten PICU length of stay. However, the viral agent detected with PCR from respiratory tract samples may be the cause of a recent infection rather than the current infection, or a different viral agent not included on the viral panel may be responsible for clinical disease. Also, only one agent is not always responsible for lower respiratory tract infections, mixed infection can also occur. It is important to discuss treatment options and duration of treatment in patients admitted to the intensive care unit. It is not appropriate to de- 
termine the same treatment approach for each patient. In our study, patients with no risk factors or no signs of bacterial infection did not receive antibiotic therapy; antibiotics were stopped in patients after viral agent positivity and sterile blood culture were confirmed. However, antibiotic therapy was continued in patients with severe illness and need for respiratory support despite positive PCR and no evidence of bacterial infection.

\section{Conclusion}

Viral infections cause LRTIs that may progress to severe respiratory distress in children. RSV, in particular, can be mortal under circumstances of co-infection or co-morbidities. Early and fast detection of viruses causing RTIs can reduce unnecessary antibiotic use and prevent antibiotic resistance. With the right diagnosis, hospital stay duration shortens and morbidity decreases.

Ethics Committe Approval: Ethics committee approval was received.

Informed Consent: Since the study was retrospective, patient concent could not be obtained.

Peer-review: Externally peer-reviewed.

Author Contributions: Concept-GŞ, AÇ; Design-AD, AA; Supervision - AÇ; Materials - ED, AC; Data Collection and/ or Processing - GŞ, AÇ; Analysis and/or Interpretation - GŞ, AÇ; Literature Review - AD, AA,AC; Writing - GŞ; Critical Review - All of authors.

Conflict of Interest: No conflict of interest was declared by the authors.

Financial Disclosure: The authors declared that this study has received no financial support.

\section{References}

1. Murray C, Lopez A, Mathers C, Stein C. The Global Burden of Disease 2000 Project: Aims, Methods, and Data Sources. Global Programme on Evidence for Health Policy. Geneva: World Health Organization; 2001.

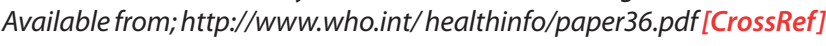

2. Tregoning JS, Schwarze J. Respiratory viral infections in infants: Causes, clinical symptoms, virology, and immunology. Clin Microbiol Rev 2010;23:74-98. "[C CrossRefif

3. McAllister DA, Liu L, Shi T, Chu Y, Reed C, Burroxs J, et al. Global, regional, and national estimates of pneumonia morbidity and mortality in children younger than 5 years between 2000 and 2015: a systematic analysis. The Lancet Global Health 2019;7:47-57. [C [ross Reff]"

4. Lozano R, Naghavi M, Foreman K, Lim S, Shibuya K, Aboyans V, et al. Global and regional mortality from 235 causes of death for 20 age groups in 1990 and 2010: a systematic analysis for the Global Burden of Disease Study 2010. Lancet (London, England) 2012;380:2095-128. [CrossRef]

5. World Health Organization WHO recommended surveillance standards, second edition. 1999. [cited 2014 Apr 12]. Available from http:// www.who.int/csr/resources/publications/ surveillance/WHO_CDS_

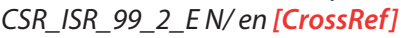

6. World Health Organization Handbook: IMCI Integrated Management of Childhood IIIness. 2005. [cited 2014 Apr 13]. Available from http:// whqlibdoc.who.int/publications/2005/9241546441. pdf ['Cross'Ref]

7. World Health Organization. World Health Statistics 2011. Geneva: World Health Organization; 2011. [CrossRef]
8. Zumla A. Killer respiratory tract infections: time to turn the tide. Curr

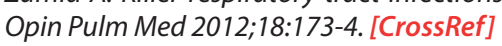

9. Akşit S. Acute respiratory tract infections-1. STED 2002; 11:132-5. [CrossRef]

10. Hatipoğlu S, Arıca S, Çelik Y, Öztora S, Şevketoğlu E, Erkum T. Alt solunum yolu enfeksiyonu tanısıyla hastanemize yatırılan olgularda RSV enfeksiyonu sıklığı ve klinik özellikleri. Düzce Tıp Fak Derg 2009;11:3844. [CrossRef]

11. Uyar R, Günaydın M, Çetin M. Alt solunum yolu enfeksiyonu olan çocuklarda viral etiyolojinin indirek immünofloresan yöntemiyle araştırılması. Mikrobiyol Bul 2000;34:339-45. [CrossRef]

12. Yüksel H, Yılmaz Ö, Akçalı S, Söğüt A, Yılmaz Çiftdoğan D, Urk V, et al. Küçük çocuklarda toplum kökenli viral alt solunum yolu enfeksiyonu etkenlerinin sıklı̆ı̆ ve uzun dönem kompliksayonu ile ilişkileri. Mikrobiyol Bul 2008;42:429-35. [CrossRef]

13. Pelit S, Bayraktar B, Bulut ME, Karabulut ND, Nuhoğlu A. Alt solunum yolu enfeksiyonu olan çocuk hastalarda viral etkenlerin immunofluoresan ve immunokromatografik yöntemler ile araştırılması. Şişli Etfal Hastanesi Tıp Bülteni 2015;49:118-21:'[C

14. Griffiths $C$, Drews SJ, Marchant DJ. Respiratory syncytial virus: infection, detection, and new options for prevention and treatment. Clin Microbiol Rev 2017;30:277-319. ["CrossRefi]

15. Jain S, Williams DJ, Arnold SR, Ampofo K, Bramley AM, Reed C, CDCEPIC Study Team. Community-acquired pneumonia requiring hospitalization among U.S. children. N Engl J Med 2015; 372:835-45. "[C CrossRefi]"

16. Eriksson $M$, Forsgren $M$, Sjöberg $S$, von Sydow $M$, Wolontis S. Respiratory syncytial virus infection in young hospitalized children. Identification of risk patients and prevention of nosocomial spread by rapid diagnosis. Acta Pediatr Scand 1983;72:47-51. '[C Cross Refi]"

17. Kuypers J, Wright N, Ferrenberg J, Huang ML, Cent A, Corey L, et al. Comparison of real-time PCR asseys with fluoresent- antibody assays for diagnosis of respiratory virus infections in children. J Clin Microbiol 2006;44:2382-8. [C CrossRef]

18. Karakoyun M, Ataoğlu EA, Büyükkayhan D, Elevli M. Solunum yolu enfeksiyonu bulguları ile başvuran 2 yaş altı çocuklarda respiratory syncytial virus enfeksiyonlarının sıklığı ve klinik özellikleri. Online Türk Sağlık Bilimleri Dergisi 2018;3:56-69. [C[rossRef $]_{1}$

19. Kanra G, Tezcan S, Yılmaz G, Turkish National Respiratory Syncytial Virus (RSV) Team. Respiratory syncytial virus epidemiology in Turkey. Turk J Pediatr 2005;47:303-8. [CrossRef]

20. Hayden FG. Rhinovirus and the lower respiratory tract. Red Med Virol

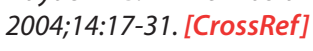

21. Akçalı S, Yılmaz N, Güler O, Şanlıbdağ T, Anıl M. Alt solunum yolu enfeksiyonu olan çocuklarda solunum yolu viral etkenlerinin sıklığı. Türk Ped Arş 2013;48:215-20. [CrossRef]

22. Frobert E, Escuret V, Javouhey E, Caselegno JS, Bouscambert-Duchamp $M$, Moulinier C, et al. Respiratory viruses in children admitted to hospital intensive care units: evaluating the CLART ${ }^{\oplus}$ Pneumovir DNA array. J Med Virol 2011;83:150-5. "[C Cross Reff]"

23. Yılmaz G, Uzel N, Işık N, Uğur S, Aslan S, Badur S. Akut alt solunum yolu infeksiyonu olan çocuklarda viral etkenler ve respiratory syncytial virüs alt grupları. Turk J Infect 2000;14:157-64. [CrossRef]

24. Lina B, Valette M, Foray S, Luciani J Stagnara J, See DM. Surveillance of community-acquired viral infections due to respiratory viruses in Rhone-Alpes (France) during winter 1994-1995. J Clin Microbiol 1996;34:3007-11. ['CrossRef $]_{1}$

25. Openshaw PJM. Potential therapeutic implications of new insights into

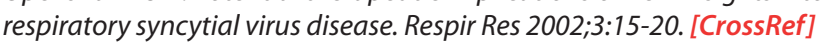

26. Shay DK, Holman RC, Roosvelt GE, Clarke MJ, Anderson LJ. Bronchiolitis associated mortality and estimates of respiratory syncytial virus-associated deaths among US children, 1979-1997. J Infect Dis 2001;183:1622.'[C [CrossRef]] 